\title{
Lymphomatoid Papulosis
}

National Cancer Institute

\section{Source}

National Cancer Institute. Lymphomatoid Papulosis. NCI Thesaurus. Code C3721.

A chronic, recurrent cutaneous disorder characterized by the presence of spontaneously regressing papules. The papules are composed of an atypical lymphocytic infiltrate that contains anaplastic CD30-positive T-cells, which are found in type A and diffuse large cell type (type C) lymphomatoid papulosis. In a small number of cases, of type B, the lymphocytic infiltrate is composed of small, cerebriform-like lymphocytes that are often negative for CD30. The majority of cases follow a benign clinical course, but some cases are clonal and may progress to lymphoma. Treatment options include low dose methotrexate and psoralen/UVA (PUVA). 